\title{
How Does The Attitude Moderate The Effect of Education, Campus Reputation and Education Facilities on The Intention of Choosing The University
}

\author{
Dadang Nugroho Darmawanto, and Budhi Haryanto
}

\begin{abstract}
This study examines the effect of educational facilities, campus reputation and costs on intentions that is mediated by attitude. The sample consisted of 100 respondents, namely high school / vocational high school students in the city of Yogyakarta who had the intention to study at AMIKOM Yogyakarta,the sample techniques used Convenience sampling. Data collection is done through surveys by giving questionnaires directly to the sample. Furthermore, the collected data was analyzed by structural equation method (SEM).The results indicate that educational facilities, campus reputation and costs have a significant and positive influence on attitudesas well as the intention of students to study at Universitas AMIKOM Yogyakarta campus. Attitudes significantly and positively affect the intention of students to choose Universitas AMIKOM Yogyakarta campus.
\end{abstract}

Keywords - educational facilities, campus reputation, costs, attitudes, intentions.

\section{INTRODUCTION}

In the current era of globalization, people are increasingly aware of the importance of getting education to a higher level. Every year students who have graduated from high school, senior high school, vocational high school and other equivalent levels will determine the steps to continue their studies at the academy, high school or college, both state and private universities. Higher education is one of the means in the implementation and development of education that can improve the quality of life of the community, nation and state. The national education system must be able to ensure equal education opportunities and improve the quality of education face challenges in accordance with the demands of changes in local, national and global life so that it needs to be done in a planned, directed and sustainable education reform. Thus, universities in Indonesia are expected to improve the quality of human life.

Many factors are behind the decision to make choices in choosing a university, including the campus product it self. [13] found two factors that influence students to study on a campus, namely campus characteristics and college effort. [14] noted that for higher education international students, the quality of education is an important factor, besides that, another factor that influences is the reputation and information about the institution.

The image of a college is usually a consideration for students in determining the educational institution they

Corresponding Author: Budhi Haryanto is an Assosiate Professor of Management at the Faculty of Economics and Business, Universitas Sebelas Maret, Indonesia. He graduated with a Doctoral degree at Universitas Gadjah Mada, Yogyakarta, Indonesia. E-mail: budhiharyanto@yahoo.com. Telp/HP: 081393902294. will choose. Higher education image can be seen from college achievement and job opportunities. Consideration of students to determine the choice in choosing a place of study including the number and qualifications of the lecturers they have, completeness of infrastructure, services provided, academic reputation, management and so on. [6] stated that international students primarily choose their higher education goals based on their academic reputation and university quality, choice of academic programs offered, and relevance and other advantages are obtained. [12] described the reputation of universities as one of the factors considered in the decision to choose a college.

This consideration is of course very relative to each person so that the cost of education is called relative education costs. Beside the two factors above [4] also found one of the factors that influence students choosing to study at an educational institution, namely costs. Cost is an assessment that depends on the ability of the economy, conditions and patterns of evaluation in a subjective manner by relating to the possible value or quality received, affordability of education costs, reasonable education costs and so on. [2] found the key factors that determine the choice of educational institutions, namely the quality of education, staff expertise, institution reputation, study programs offered, and marketing promotions and efforts.

There are many colleges that have bachelor programs in Indonesia. College can be academies, polytechnics, institutes or universities. The ability to obtain students depends on the delivery of information or promotion about the relevant university. Universities as providers of products in the form of education services must be able to recognize the target market they are targeting. One of the universities in Indonesia is Universitas AMIKOM which is located in Yogyakarta City. Universitas AMIKOM has the same opportunity as other universities to be chosen by prospective students in continuing their studies. Based on the description, it is known that educational facilities, campus reputation and costs are closely related to students' attitudes to choosing a school in the future. This attitude is what ultimately becomes an important factor that influences the intention of students choosing to study on a campus.

This research is a development of previous research conducted by 1. [13] found that there are two factors that influence students to study on a campus namely campus characteristics and college effort., 2. [14] noted that for higher education international students, the quality of education is an important factor, besides that other factors that influence are reputation and information about the institution, 3. [6] stated that international students primarily choose their higher education goals based on their academic 
reputation and the quality of the university, the choice of academic programs offered, and relevance and other advantages gained. 4. [4] also found one of the factors that influenced students to choose college at an educational institution, namely costs, and 5. [2] found the key factors that determine the choice of educational institutions, namely the quality of education, staff expertise, institution reputation, study programs offered, and marketing promotion and efforts.

\section{LITERATURE REVIEW AND HYPOTHESES}

Attitude is a reflection of a person towards an object that can affect his/her behavior towards the object. Attitudes are formed through two components, namely belief in the consequences of certain behaviors and evaluations of consequences [21]. Belief in the consequences of certain behaviors contains aspects of certain behavioral knowledge. If it is associated with the student's intention to choose a lecture, then the belief component contains educational facilities.

Students will certainly give an assessment of which campus they choose. The assessment will certainly not be separated from the beliefs and evaluations made by the student. These assessments are certainly very dependent on how much information is received by the student. [13] found two factors that influence students to study on a campus, namely campus characteristics and college effort. Physical education facilities refer to school conditions, namely,school buildings, classrooms, libraries, laboratories, toilet facilities, offices and other facilities and infrastructure that will motivate students to learn. Educational facilities are closely related to effective learning and student academic performance [3]. [2] found factors that influence students to study, namely recommendations of friends, campus reputation, quality of education and state image. Based on the description, the first hypothesis can be made as follows.

$\mathrm{H}_{1}$ :There is a positive relationship between educational facilities and positive attitude towards AMIKOM university.

Campus reputation in this case is the image of an educational institution or university image. If a university has a positive image in the eyes of the community, it will automatically form the mind in the minds of the community that the university has good quality. Which will then has an impact on the decision of the community or consumers to continue their studies at the university.

The reputation of the campus in the minds of consumers arises because the process of perception, how consumers assess a service quality is also largely determined by its perception, success in positioning the product is also very dependent on perceptions in the minds of consumers. A good college reputation will have a good position in the minds of prospective students. When prospective students have the desire to continue their higher education, only universities that are in the minds of prospective students are considered.

[16] explained that image analysis of higher education institutions and study programs was based on student perceptions of the university's existence knowledge, level of prestige, and university status. Every college will try to improve the image of universities so that they can positively place themselves for students and prospective students. The perception of the reputation of the college will be one of the variables evaluated by prospective students. [9] stated that the perceived image position of the consumer will lead to a positive attitude. [1] found one factor that influences students choosing a campus is learning and job opportunities.Based on the description, the second hypothesis can be made as follows.

$\mathrm{H}_{2}$ : There is a positive relationship between campus reputation and positive attitude towards AMIKOM university.

Prices in the world of education are costs set by universities to students to attend lectures. Prospective students will assess the fairness of an educational price by comparing prices set by Universitas AMIKOM Yogyakarta compared to prices from other universities. Prospective students will also consider their economic ability to choose universities so that the fair price is a price that can be reached by prospective students. [4] also found one of the factors influencing students to choose college at an educational institution, namely costs. Research of [17] states that the cost of living and the cost of education are factors that influence students toattend school in Turkey. Based on the description, the third hypothesis can be made as follows. $\mathrm{H}_{3}$ : There is a positive relationship between the fairness of cost and positive attitude towards AMIKOM University

Universities in businesses engaged in services, then all existing facilities, namely the condition of facilities, completeness, interior design, and cleanliness of facilities must be considered, especially those that are closely related to what the consumer feels or gets directly.The facility itself is a physical resource that must exist before a service can be offered to consumers. Facilities provided by high-ranking universities greatly influence consumer decisions, because they are closely related to customer perception formation. The closeness of the relationship can be seen from the tendency seen in the current product market, where consumers have a desire for the product to have complete facilities. Research of [17] stated that educational facility is a factor that influences students to study in Turkey. [1] found one of the factors influencing students to choose a campus: facilities, computer laboratories and libraries.Complete educational facilities are needed by the university to support the process of teaching and learning activities. Students will feel comfortable in studying if all the facilities needed can be available in the vicinity.Based on the description, the fourth hypothesis can be made as follows.

$\mathrm{H}_{4}$ : There is a positive relationship between educational facilities and intentionto choose AMIKOM university.

[19] stated that the knowledge of students' perceptions about the image of higher education can help institutions to understand students and strategies that can be implemented. Colleges need to improve introduction and knowledge of prospective students so that a good reputation is obtained about the college. [12] describe the reputation of higher 
education as one of the factors considered in the decision to choose college. This statement is supported by [7] states that the institution's reputation will influence the intention of prospective students. College reputation consists of teaching quality, prestige, international recognition, communication, and facilities on campus. [11] stated that career opportunities after graduation and academic reputation are two of the institutional characteristics that most influence the choice of universities, while parents or trustees are the people who provide the strongest influence during the decision making process.

In this study the dimensions studied are a function of the reputation of universities perceived by prospective students. Perceptions of the reputation of higher education will produce interest from prospective students to continue their studies at a college. The more positive the perception of the image of a college, the higher the desire of prospective students to continue their studies. Based on these statements, the hypothesis tested is:

$\mathrm{H}_{5}$ : There is a positive relationship between campus reputation and intention to choose AMIKOM University.

Students will have a lot of consideration in choosing a place of study including costs that must be incurred. Costs not only can be assessed in terms of high and low, expensive or not, but can also be seen from the other side, namely on how the ability, perceiving and feeling the costs incurred are associated with the facilities obtained from the college. [12] in their research stated that the educational costs set by the institutionbecome one of the considerations of prospective students to conduct college selection. The cost of education is based on an economic approach that students assume is rational and makes decisions about costs and benefits carefullyby considering all available alternatives. Research [5] stated that one of the factors that influence students' decisions in Southeast Asia in choosing a place to study is the cost of education. Students willcalculate the costs that must be incurred during college. Based on various studies on the perception of education prices and intentions it can be indicated that prospective students will be motivated to raise the intention of choosing a college ifthe prices set by universities are considered reasonable and in accordance with the quality offered. Based on the description, the sixth hypothesis can be made as follows.

$\mathrm{H}_{6}$ : There is a positive relationship between the fairness of cost and intention to choose AMIKOM University

Intention is the desire to conduct behavior. Intention is not always static, but can change over time [22]. Intention is not yet a behavior while behavior is an actual action or activity carried out [10]. [20] stated that the process of selecting universities would go through three stages of the decision making process. The first stage is the prospective students are encouraged to continue their education to college. The second stage is prospective students starts to looking for and obtaining information about the attributes of higher education to be considered in determining which college. The third stage is prospective students compares and evaluates various alternatives in terms of higher education and the most important naturefor them so that the intention arises to choose a college. Based on this description, the seventh hypothesis can be made as follows.

$\mathrm{H}_{7}$ : There is an influence on attitudes towards students' intention to choose AMIKOM Univetrsity

\section{RESEARCH METHODS}

\section{A. Sample}

Respondents in this study were high school / vocational high school students who intend to choose AMIKOMUniversity Yogyakarta. The amount of sample is 100 people. The sampling technique in this study uses convenience sampling technique with the criteria of high school/vocational high school students who are studying at tutoring places such as Primagama, Neutron and Ganesha Operation, sports venues such as the Lembah UGM, UNY GOR and Amongrogo and public areas such as Jogja City Library, JEC, Alun-alun Kidul and XT Square.

\section{B. Measurement}

Educational facilities are assessments made by individual high school / vocational high school students regarding their physical appearance and comfort (facilities and infrastructure) owned and offered by Universitas AMIKOM to support lecture activities. The educational facilities are shown using the following measurement items: 1. Nice, 2. Complete, 3. Good, 4. Modern, and 5. Comfortable.

Campus reputation is the individual perception of high school / vocational school students towards professionalism from Universitas AMIKOM. Campus reputation is a subjective picture made by individuals as a result of various information andperception of something. The campus reputation is shown by using the following measurement items: 1. Good reputation, 2. Recognized by the public, 3. Get an award, 4. Have achievements, and 5. High accreditation.

According to [15] perception is a series of complicated processes through which we obtain and interpret sensory information. Education costs are one of the most important instrumental components (instrumental input)in the administration of education. Costs in this sense have a broad scope, namely all types of expenditure relating to the administration of education, both in the form of money and goods and labor (which can be priced in money). The cost of education is the overall financial sacrifice incurred by parents of students for the needs during education from the beginning to the end of education. Whether it's registration fees and credits every semester, the cost of donating building construction, welfare funds and student facilities per semester and other tuition fees which include the costs of developing and financing curricular and extra curricular activities, equipment book fees, State examination fees, as well as other education costs used to support lectures. Indicators or fairness of cost: 1. Normal, 2. Transparent, 3. Affordable, 4. Cheap, and 5. Competing.

Attitude is an assessment or tendency of high school / vocational high school students to choose to study at the campus of Universitas AMIKOM. Attitudes put individuals in a frame of mind about the likes or dislikes of something, approaching or staying away fromsomething and this 
attitude is difficult to change. The attitude is shown by using measurement items that refer to the following [18] research: 1. Gladto be accepted at Universitas AMIKOM, 2. Like being a student at Universitas AMIKOM, 3. Happy to have the opportunity to study at Universitas AMIKOM, 4. Many positive values were obtained at Universitas AMIKOM, and 5. Happy being a student at Universitas AMIKOM.

Intention of choosing to study at Universitas AMIKOMcampus is the intention that arises from within high school / vocational high school students to study at Universitas AMIKOM. Intention to choose college on campus is measured based on the interest of high school / vocational high school students in looking for information about Universitas AMIKOM, considering choosing the campus as a place to study. The intention to choose the place of study is indicated by using measurement items that refer to the following researches of [18]: 1 . Tend to study at Universitas AMIKOM, 2. Hoping to be accepted to study at Universitas AMIKOM, 3. Certainly will study at Universitas AMIKOM, 4. Most likely will study at Universitas AMIKOM, and 5. Will choose Universitas AMIKOM as a place to study compared to other campuses.

All of item is measured using a Likert scale ( $1=$ strongly disagree $-5=$ strongly agree) [8].

\section{RESULT AND DISCUSSION}

\section{A. Assumption the Goodness of Fit Model}

Table 1 shows a summary of the results obtained in the study and recommended values for measuring the fit model. The main condition for the MLE (Maximum Likehood Estimate) model is the fulfillment of the Chi-Square probability value.As shown in the table above, of the seven model fit minimum requirements, all are met by the SEM measurement results. In the table it can be stated that the fit model is fulfilled because it is known that the chi-square value is 1.000 , prob. $>.05$. Goodness of fit that has met the requirements of showing the model can explain the phenomenon that must be explained. Furthermore, in this study there is no need to modify the model.

Table 1. Evaluation of Goodness-of-Fit Indices

\begin{tabular}{lccc}
\hline \multicolumn{1}{c}{ GOF Index } & Cut-off value & Results & Conclusion \\
\hline$\chi^{2}-$ Chi-Square & Expected small & 112,881 & Fit \\
Significance probability & $\geq .05$ & 1.000 & Fit \\
CMINDF & $\leq 2.00$ & .421 & Fit \\
GFI & $\geq .90$ & .918 & Fit \\
AGFI & $\geq .90$ & .901 & Fit \\
RMSEA & $\leq .08$ & .000 & Fit \\
PCFI & $\geq .50$ & .893 & Fit \\
TLI & $\geq .95$ & 1.219 & Fit \\
CFI & $\geq .95$ & 1.000 & Fit \\
RMR & $\leq .50$ & .047 & Fit \\
\hline
\end{tabular}

\section{B. Hypothesis testing}

After the criteria for goodness of fit in the structural model are fulfilled, then the next stage is structural analysis of the model of the relationship between variables. The relationship between constructs in the hypothesis is indicated by the regression weight value. Table 2 presents the regression weights of the variables tested. Hypothesis testing is done by analyzing the level of causality significance between constructs in the model based on the $\mathrm{CR}$ value that has a higher than or equal to $\mathrm{z}$-table. The $\mathrm{z}$ value table for each level of significance is: $1 \%=2.576 ; 5 \%$ $=1.96 ; 10 \%=1.645$. Testing the hypothesis by comparing the numbers in the $\mathrm{CR}$ (Critical ratio) column and the $\mathrm{P}$ (Probability) column with the required statistical limits of 1.96 as $\mathrm{t}$ table and .05 as alpha $(\alpha)$. Hypothesis testing. Significant if the CR value is $>1.96$ and the value of $\mathrm{P}<.05$. Strength of influence can be seen in the estimate value on the calculation results as follows.

Table 2. Hypothesis Testing Results

\begin{tabular}{|c|c|c|c|c|c|c|}
\hline \multicolumn{3}{|c|}{ Variable Relationships } & \multirow{2}{*}{$\begin{array}{r}\text { Estimate } \\
.270\end{array}$} & \multirow{2}{*}{$\frac{\text { S.E. }}{.102}$} & \multirow{2}{*}{$\frac{\text { C.R. }}{2.636}$} & \multirow{2}{*}{$\frac{\mathrm{P}}{.008}$} \\
\hline Attitude & $<---$ & Cost & & & & \\
\hline Attitude & $<---$ & Reputation & .365 & .163 & 2.238 & .025 \\
\hline Attitude & $<---$ & Facilities & .320 & .097 & 3.298 & *** \\
\hline Intention & $<---$ & Cost & .185 & .082 & 2.242 & .025 \\
\hline Intention & $<---$ & Attitude & .425 & .127 & 3.338 & *** \\
\hline Intention & $<---$ & Facilities & .171 & .079 & 2.149 & .032 \\
\hline Intention & $<---$ & Reputation & .276 & .130 & 2.116 & .034 \\
\hline
\end{tabular}

\section{Discussions}

\section{Relationship between Educational facilities and Attitude}

The first hypothesis states that there is a relationship between Educational facilities and Attitude. Regression coefficient value of .320 shows the value of Educational facilities variables on Attitude. C.R value of Educational facilities towards Attitude equal to 3,298>1,96 with p-value value at $* * *<.05$ shows that the variables of Educational facilities and Attitude are significant. Based on the regression value, C.R value, and p-value value then the test results show that Educational facilities have a positive effect and have a significant relationship to Attitude. Based on the results obtained, $\mathrm{H} 1$ is accepted.

The results of this test are in accordance with hypothesis 1 which states that the higher the Educational facilities, the higher the Attitude. This can occur when consumers have positive knowledge and perceptions about Educational facilities, then it directs consumers to like and form positive attitudes towards variables Educational facilities.

These findings support the previous research hypothesis which explains that the better Educational facilities the higher the positive Attitude of prospective students [13]. Physical education facilities refer to school conditions, namely, school buildings, classrooms, libraries, laboratories, facilities for toilets, offices and other facilities and infrastructure that will motivate students to study. Educational facilities are closely related to effective learning and student academic performance [3].

Furthermore, this finding can be used as a reference in designing marketing strategies, especially with the marketing of Universitas AMIKOM. The intended strategy is to cooperate with other companies to improve Educational facilities. This aims to build the confidence of prospective students in the ability of Universitas AMIKOM to improve educational facilities. Related to further research, althoughthis study shows significant and positive results that provide support to the concept of a positive relationship 
between educational facilities and Attitude, but further testing is needed to improve the concept of hypothesis generalization. Thus, the concept hypothesized in this study has a wider and different level of application both in terms of objects and research settings.

\section{Relationship between Campus Reputation and Attitude}

The second hypothesis states that there is a relationship between Campus Reputation and Attitude. The regression coefficient value is .365 , which shows the influence of Campus Reputation on Attitude positively. C.R value of Campus Reputation on Attitude is 2.238> 1.96 with a pvalue at a significant level of $.025<.05$ indicating the value of the relationship between these variables is significant. Based on regression values, C.R values and $p$-value values, so the test results show that Campus Reputation has a positive effect and has a significant relationship to Attitude. Based on the results obtained, H2 is accepted.

The results of this test are in accordance with hypothesis 2 which states that the more Campus Reputation, the higher the Attitude. The results of this test indicate that Campus Reputation is an important variable to encourage positive Attitude to Universitas AMIKOM. This can happen when consumers have high knowledge and perceptions of Campus Reputation, so this will lead prospective students to like and form a positive attitude towards Universitas AMIKOM.

These findings support the previous research hypothesis which explains that the higher the Campus Reputation, the higher the Attitude [16]. Every college will try to improve the image of universities so that they can positively place themselves for students and prospective students. The perception of university reputation will be one of the variables evaluated by prospective students. [9] states that the perceived image position by consumers will lead to positive attitudes. [1] also found one factor that influences students choosing a campus is learning and job opportunities.

Furthermore, this finding can be used as a reference in designing marketing strategies, especially with regard to marketing of higher education services. The strategy in question is to improve marketer skills in creating, maintaining, protecting and raising Campus Reputation. Companies must periodically audit brand strengths and weaknesses. Brand may need to be repositioned if there is a change in customer preferences or the existence of a new competitor, this aims to build and manage the brand effectively. Related to further research, although this study shows significant and positive results that provide support to the concept of a positive relationship between Campus Reputation and Attitude, but further testing is needed to improve the concept of generalizing hypotheses. Thus, the concept hypothesized in this study have a wider and different level of application both in terms of objects and research settings.

\section{The relationship between Cost and Attitude}

The third hypothesis states that there is a relationship between Cost and Attitude. The value of the regression coefficient of .270 which shows the variable Cost has a positive influence on Attitude. C.R value of 2.636> 1,96with a p-value at a significant level $.008<.05$, the relationship between these variables is significant. Taking into account the regression value, C.R value and p-value value, the test results show that Cost has an effect positively and have a significant relationship to Attitude. Based on the results obtained, H3 is accepted.

The results of this test are in accordance with hypothesis 3 which states that the higher the perception of Cost, the higher the Attitude. The results of this test indicate that Cost perception is an important variable to encourage positive Attitude to Universitas AMIKOM. This can happen when consumers have positive knowledge and perceptions about Cost that direct consumers to like and form a positive attitude towards Universitas AMIKOM.

These findings support the previous research hypothesis which explains that the higher the reasonable perception of Cost, the more positive the Attitude [18]. [4] also found one of the factors influencing students to choose college in an educational institution, namely Cost. Research [17] stated that Cost of living and Cost of education are factors that influence students to study in Turkey.

Furthermore, this finding can be used as a reference in designing marketing strategies, especially with regard to marketing of higher education services. The strategy in question is to increase production capability at Universitas AMIKOM so that it can create a cheap Cost because of the education subsidy from production. Associated with further research, although this study shows significant and positive results that provide support tothe concept of a positive relationship between Cost and Attitude towards the Universitas AMIKOM. Further testing is needed to improve the concept of generalizing hypotheses. Thus, the concept is hypothesized within this research has a wider and different level of application both in terms of objects and research settings.

\section{Relationship between Educational facilities and \\ Intention}

The second hypothesis states that there is a relationship between Educational facilities and Intention. The value of the regression coefficient is .171 which indicates the influence of Educational facilities variables on Intention. C.R value of Educational facilities towards Intention are $2.149>1.96$ with $\mathrm{p}$-value at $.032<.05$ indicating that the relationship between these variables is significant. Based on the regression value, C.R value, and p-value, then the test results shows that Educational facilities have a positive effect and have a significant relationship to Intention. Based on the results obtained, $\mathrm{H} 4$ is accepted.

The results of this test are in accordance with hypothesis 4 which states that the higher the perception of Educational facilities, the higher the Intention. This can happen when consumers have positive knowledge and perceptions about Educational facilities, so that directing consumers to form Intention to choose college at AMIKOM University.

These findings support the previous research hypothesis which explains that Educational facilities are factors that influence students to study in Turkey [17]. [1] found one of the factors that influence students choosing a campus is Facilities, computer laboratories and libraries. Complete 
educational facilities are needed by the university to support the teaching process and learning activities. Students will feel comfortable in studying if all the required facilities can be available in the vicinity.

Furthermore, this finding can be used as a reference in designing marketing strategies, Universitas AMIKOM which uses Educational facilities variables in promoting its lectures. Associated with research, continuation is needed to improve the hypothesis concept with different conditions. Thus, the concept hypothesized in this study has a broader and different level of application, both in terms of objects and research settings.

\section{Relationship between Campus Reputation and Intention}

The fifth hypothesis states that there is a relationship between Campus Reputation and Intention. The regression coefficient value of .276 shows the influence of a high Campus Reputation variable on Intention positively. The C.R value of Campus Reputation against Attitude is 2.116> 1.96 with a p-value of $.034<.05$ indicating the value of the relationship between these variables is significant. Based on the regression value, C.R value and p-value value, then the test results shows that Campus Reputation has a positive influence and has a significant relationship to Intention. Based on the results obtained, H5 is accepted.

These findings support the previous research hypothesis which explains that university reputation as one of the factors considered in the decision of college selection [12]. This statement is supported by [7] stated that Reputation of institutions or university Reputation will influence Intention of prospective students. College reputation consists of teaching quality, prestige, international recognition, communication, and facilities on campus.

Furthermore, this finding can be used as a reference in designing marketing strategies, especially with regard to university marketing. The strategy in question is not to consider Campus Reputation variables to awaken the Intention of prospective students to choose to study at the Universitas AMIKOM. Intention of prospective student lectures directly will not be influenced by Campus Reputation variables. Further research is needed to improve the concept of generalizing hypotheses. Thus, the concept hypothesized in this study has a wider and different level of application both in terms of objects and research settings.

\section{Relationship between Fairness of Cost and Intention}

The sixth hypothesis states that there is a relationship between Cost and Intention. The regression coefficient value of .185 shows the influence of Cost on Intention positively. The value of C.R Cost to Attitude is equal to 2,242> 1,96 with a p-value at $.025<.05$ shows the relationship between these variables is significant. Considering the regression value, C.R value and $p$-value value, the test results show that Cost has a positive and positive effect has a significant relationship to Intention. Based on the results obtained, H5 is accepted.

The results of this test are in accordance with hypothesis 5 which states the higher perception of Cost, the higher the Intention. This can occur when consumers have positive knowledge and perceptions about Cost, it can lead consumers to form Intention choose to study at Universitas AMIKOM.

The results of this test support the previous hypothesis which explains that the cost of education set by the institution is one of the considerations of prospective students to conduct college selection [12]. Cost education is based on an economic approach that students assume is rational and makes cost decisions and benefits carefully by considering all available alternatives. [5] mentions that one of the factors influencing students' decisions in Southeast Asia in choosing a place to study is the cost of education.

This finding can be used as a reference in designing marketing strategies, especially with regard to marketing of higher education services. The strategy in question is to provide various solutions to overcome variable Cost to create lecture Intention. These solutions include related payment and scholarship methods. Related to further research is needed to improve the concept of generalizing hypotheses. Thus, the concept hypothesized in this study has a wider and different level of application both in terms of objects and research settings.

\section{Relationship between Attitude and Intention in college}

The seventh hypothesis states that there is a relationship between Attitude and Intention. The value of the regression coefficient of .425 shows the influence of Attitude variables on Intention positively. C.R Attitude value against Intention of $3.338>1.96$ with a p-value $=<.05$ indicates the value of the relationship between these variables is significant. Considering the regression value, C.R value and $p$-value value, the test results show that Attitude has a positive influence and has a significant relationship to Intention. Based on the results obtained, H7 is accepted.

These findings support the previous research hypothesis explains that the process of selecting universities will go through three stages of the decision making process [20]. The first phase, prospective students' desire to continue their education to tertiary institutions is fostered. In the second stage prospective students begin to search for and obtain information about the attributes of higher education to be considered in determining which universities. The third stage, prospective students compare and evaluate various alternatives in terms of tertiary education and the most important traits for them so that Intention appears to choose a college.

This finding can be used as a guideline in formulating a marketing strategy, namely packaging various aspects of university socialization with clearer goals and complete information so that it will affect consumer attitudes to raise Intention, choose to study at the Universitas AMIKOM. Related to further research, although this study shows significant and positive results that support positive relationships between Attitude to advertising and Intention to buy, but further testing is needed to improve the concept of hypothesis generalization. Thus, the concept hypothesized in this study has a wider and different level of application both in terms of objects and research settings. 


\section{CONCLUSIONS AND RECOMENDATIONS}

The results of this study are Educational facilities, Campus Reputation and Cost significantly and positively affect the Attitude and Intention of students choosing to study at the Universitas AMIKOM Yogyakarta campus. Attitude has a significant and positive effect towards students' Intention to choose to study at the campus of Universitas AMIKOM Yogyakarta. The results of the study are expected to be used as a reference for higher education managers to develop strategies in order to increase recruitment of prospective students.

Universitas AMIKOM must always improve the quality of teaching and learning activities so that it can improve the quality of the results of its graduates. Through this quality improvement will bring positive perceptions and attitudes of prospective new students. Universitas AMIKOM enhances Educational facilities and increases cooperation with various alumni users. Facilities that are more complete and open employment opportunities will create a reasonable and positive perception of Cost to build an increasingly positive attitude. Universitas AMIKOM must be able to improve Campus Reputation to prospective students. This Campus Reputation can be done through achievements obtained from various educational activities, training and various social activities for example training activities for the community, participating in exhibition activities, organizing sports championships, and others. Marketing Strategies designed and developed by Universitas AMIKOM must be strategies that can influence or shape the Attitude of prospective students.

\section{REFERENCES}

[1] Agrey, L, \& Lampadan, N. 2014. Determinant Factors Contributing to Student Choice in Selecting a University. Journal of Education and Human Development, Vol. 3, No. 2, pp. 391-404.

[2] Ahmad, S.Z., Buchanan, F.R., \& Ahm,a, N. 2016. Examination of students' selection criteria for international education.International Journal of Educational Management, Vol. 30, No.6, pp. 1088-1103.

[3] Akomolafe, C.F., \& Adesua, V.O. 2014. The Impact of Physical Facilities on Students' Level of Motivation and Academic Performance in Senior Secondary Schools in South West Nigeria.Journal of Education and Practice, Vol.7, No.4, pp. 38-42.

[4] Anderson, R., \& Bhati, A., 2012. Indian Students' Choice of StudyDestination: Reasons for Choosing Singapore. International Journal of Innovative Interdisciplinary Research, Issue 2, pp. 66-76.

[5] Baharun, R., Awang, Z., \& Padlee, S.F. 2011. International students' choice criteria for selection of higher learning in Malaysian private universities. African Journal of Business Management, Vol.5, No.12, pp. 4704 -4714.

[6] Choi, S. \& Nieminen, T. 2013. Factors influencing the higher education of internationalstudents from Confucian East Asia, Higher Education Research \& Development, Vol. 32, No. 2 .

[7] Cubilo, Sanchez, \& Cervinho. 2006, International Students Decision Making Process, International Journal of Educational Management, Vol. 20 Iss 2 pp. $101-115$.

[8] Ferdinand, A. 2006.Metode Penelitian Manajemen. Semarang: Badan. Penerbit Universitas Diponegoro.

[9] Haryanto, B. 2009, Efikasi Diri, Kualitas Pengajaran, Attitude Positif, dan Kinerja Akademis Mahasiswa, Jurnal Ilmu Pendidikan, Jilid 16, Nomor 3, Oktober 2009, hlm. 152-161.

[10] Haryanto, B., Febrianto, A., \&Cahyono, E. 2019. Lifestyle and Consumer Preferences in Choosing Local or Foreign Brands: A Study of Consumer Behavior in Surakarta-Indonesia. Jurnal Manajemen dan Kewirausahaan. Vol 21, No 1, pp 75-89.
[11] Hereen, C.D., Cartmell, D.D., \& Robertson, J.T. 2011.Perceptions of Influenceon College Choice by Students Enrolled in a College of Agricultural Sciences and Natural Resource, NOACTA Journal, Vol. 1, No. 1, pp: 54-61.

[12] Joseph, M., Mullen, E.W., \& Spake, D.. 2012, University branding: Understanding students ' choice of an educational institution, Journal of Brand Management Vol. 20, No.1, pp.1-12.

[13] Kee-Ming, J.S., 2010, Institutional Factors Influencing Students' College Choice Decision in Malaysia:A Conceptual Framework. International Journal of Business and Social Science, Vol.3, No.3, pp: 53-58.

[14] Lee, C.-F. 2014, An investigation of factors determining the study abroad destination choice: a case study of Taiwan, Journal of Studies in International Education, Vol. 18 No. 4, pp: 362-381.

[15] Ling, J., \& Catling, J. 2012. Cognitive psychology. Pearson Prentice Hall.

[16] Misran, et. al. 2012. Influencing Factors for Matriculation Students in Selecting University and Program of Study, 3 Procedia-Social and Behavioral Sciences, Vol. 60, pp: 567-574.

[17] Özoğlu,M., Gür, B.S., \& Coşkun, I. 2015. Factors influencing international students' choice to study in Turkey and challenges they experience in Turkey. Research in Comparative \& International Education, Vol. 10, No. 2, pp: $223-237$.

[18] Setiawan, M. M., \& Haryanto, B. 2014. The antecedent variables of attitude in forming intention to switch smartphone. European Journal of Business and Social Sciences, 3, No 6, pp 126-135.

[19] Shah \& Nair. 2010. Enrolling in Higher Education: The Perceptions of Stakeholders, Journal Institutional Research, Vol. 1, pp. 9-15.

[20] Sidin, Hussin \& Soon. 2003. An Exploratory Study of Factors Influencing the College Choice Decision of Undergraduate Students in Malaysia, Asia Pacific Management Review, Vol 8, No.1, pp 259280 .

[21] Southey, G. 2011. The theories of reasoned action and planned behaviour applied to business decisions: a selective annotated bibliography, Journal of New Business Ideas \& Trends, Vol. 9, No. 1, pp. $43-50$.

[22] Triyanto, T., \& Cahyono, E. 2016. Analisis niat berwirausaha mahasiswa ditinjau dari perspektif pendekatan psikologis. Buletin ekonomi jurnal manajemen, akuntansi dan ekonomi pembangunan, Vol 14, No 2, pp 160-176.

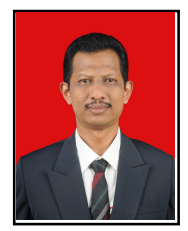

Dadang Nugroho Darmawanto, SE. Author is a Magister Management student at Faculty of Economics and Business, Universitas Sebelas Maret, Indonesia. He is an Lecturer of Management at the Universitas AMIKOM, Yogyakarta, Indonesia

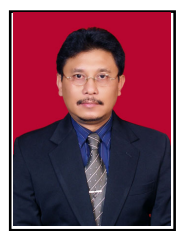

Dr. Budhi Haryanto, MM. He is an Assosiate Professor of Management at the Faculty of Economics and Business, Universitas Sebelas Maret, Indonesia. He graduated with a Doctoral degree at Universitas Gadjah Mada, Yogyakarta, Indonesia. 